\title{
Perancangan Sistem Informasi Pelayanan Kesehatan UPTD Puskesmas XYZ
}

\author{
Dudi Awallludin ${ }^{1}$, Agustin Eka Wulandari ${ }^{2}$ \\ Program Studi Sistem Informasi, STMIK Rosma, Karawang, Indonesia ${ }^{1}$ \\ Program Studi Manajemen Informatika, STMIK Rosma, Karawang, Indonesia ${ }^{2}$ \\ Email :dudi@rosma.ac.id ${ }^{1}$, agustin_ekawulandari@outlook.co.id ${ }^{2}$
}

\begin{abstract}
Abstrak
UPTD Puskesmas XYZ merupakan salah satu pusat pelayanan kesehatan tingkat pertama yang melayani 1034 pasien pada bulan Desember 2016. Untuk melakukan pengolahan data sebanyak itu masih dilakukan secara manual di mulai dari pendaftaran sampai pencatatan rekam medis (RM). Pengelolaan data pasien dan rekam medis masih menggunakan formulir untuk melakukan pendaftaran dan mencatat data pasien pada buku 1034 pasien pada bulan Desember 2016. Melihat beban bagian pendaftaran dalam mencatat pendaftaran dan pencarian data pasien serta pencarian Kartu Status Pasien (KSP) harus dilakukan secara manual. Model Waterfall merupakan salah satu model dalam pengembangan sistem, dimulai dengan pengumpulan data dengan menggunakan metode observasi, wawancara, studi pustaka, dan studi dokumentasi atas sistem yang berjalan. Tahapan berikutnya perancangan sistem, alat yang digunakan adalah flowchart, Entity Relationship Diagram (ERD), dan Data Flow Diagram (DFD). Perancangan sistem pelayanan kesehatan berbasis web ini diharapkan dapat dibangun suatu sitem untuk menunjang di bagian pendaftaran dalam memudahkan melakukan pencarian data pasien serta pengelolaan dari data pasien hingga rekam medis dengan cepat, tepat dan akurat.
\end{abstract}

Kata Kunci : sistem informasi, pelayanan kesehatan, puskesmas.

\begin{abstract}
The UPTD Puskesmas XYZ is one of the first-level health service centers that served 1034 patients in December 2016. To do so much data processing is still done manually, starting from registration to recording medical records (RM). Management of patient data and medical records still uses forms to register and record patient data of 1034 patients in December 2016. Seeing the burden of the registration section in recording registration and searching of patient data and searching for Kartu Status Pasien (KSP) must be done manually. The Waterfall Model is one of the models in the development of the system, starting with the stages of data collection using the method of observation, interviews, literature study, and documentation studies of the running system. The next stage is system design, the tools used are flowcharts, Entity Relationship Diagrams (ERD), and Data Flow Diagrams (DFD). Health service system design web based is expected to built a system to assist the registration in facilitate the search for patient data and management from patient data to medical record quickly, precisely and accurately.
\end{abstract}

Keywords : information systems, health care, puskesmas

\section{Pendahuluan}

Penerapan Teknologi Informasi saat ini tidak hanya pada jenis kegiatan tertentu. Akan tetapi telah memasuki semua jenis kegiatan usaha seperti Pemerintahan, Perdagangan serta Perindustrian sekalipun, termasuk Dinas Kesehatan yang dibawah naungan Pemerintahan Daerah, dimana Puskesmas sebagai Unit Pelaksana Teknis Daerah (UPTD) yang berkaitan dengan diperolehnya informasi kesehatan. Sistem informasi kesehatan pada puskesmas adalah suatu tatanan yang menyediakan informasi untuk 
membantu proses pengambilan keputusan dalam melaksanakan kegiatan manajemen puskesmas dalam mencapai sasaran kegiatannya [1].

Pusat kesehatan masyarakat (Puskesmas) adalah suatu kesatuan organisasi kesehatan fungsional yang merupakan pusat pengembangan kesehatan masyarakat yang juga membina peran serta masyarakat di samping memberikan pelayanan secara menyeluruh dan terpadu kepada masyarakat di wilayah kerjanya dalam bentuk kegiatan pokok [2]. Masyarakat yang terdapat di lingkungan pedesaan merupakan salah satu wilayah kerja puskesmas dalam pelayanan gangguan kesehatan dan kecelakaan [3].

Penelitian yang sudah pernah dilakukan mengenai sistem informasi pelayanan kesehatan diantaranya : penelitian tentang pemaparan pendaftaran pasien rawat jalan untuk pasien Jamkesmas dan Askes PNS yang belum memanfaatkan sistem informasi. Kesimpulan hanya merancang pendaftaran pasien dan Laporan kunjungan pasien [4], penelitian tentang pembuatan indeks penyakit, indeks tindakan, indeks dokter, dan indeks pasien secara otomatis serta pembuatan laporan tentang 10 besar penyakit tercatat pada rekam medis [5], penelitian ini membahas tentang perancangan sistem pelayanan kesahatan prima terpadu di Kediri, menitikberatkan pada pembahasan pengelolaan data administrasi pasien, menggunakan perancangan database conceptual dan logical,model [6], penelitian berikutnya yaitu penelitian tentang digitalisasi surat rujukan pada suatu puskesma di Garut sehingga dapat mempermudah dalam pembuatan dan pengarsipan surat rujukan [7], serta penelitian pada jurnal ini mentitikberatkan pada digitalisasi Rekam Medis sehingga mempermudah dalam pembuatan laporan [8].

Puskesmas seringkali tidak kita manfaatkan secara maksimal, dikarenakan pelayanan yang diberikan oleh pihak terkait terkadang kurang memuaskan. Khususnya pada pengelolaan data pasien, mulai dari pendaftaran, pembuatan rujukan hingga pengarsipan rekam medis pasien. Setiap data yang seharusnya ada dan disimpan di Puskesmas seringkali tidak kita temui atau sulit untuk dicari. Selain itu, sering terjadi keterlambatan dan kesulitan dalam memberikan pelaporan kepada petugas Sistem Pencatatan dan Pelaporan Puskesmas (SP3) dikarenakan sistem yang digunakan belum menggunakan komputer. Agar bisa lebih mengoptimalkan sistem tersebut, dibutuhkan pengembangan sistem dengan menggunakan teknologi informasi. Dengan adanya pengembangan sistem dari sistem manual ke sistem terkomputerisasi maka diharapkan informasi yang diperoleh akan lebih cepat, akurat, dan efisien.

\section{Kajian Pustaka}

Sistem adalah suatu kumpulan atau himpunan dari unsur, komponen, atau variabel yang terorganisasi, saling berinteraksi, saling bergantung satu sama lain dan terpadu [9]. Sedangkan informasi adalah data yang diolah menjadi bentuk yang lebih berguna dan berarti bagi penggunanya [10]. Berdasarkan definisi sistem dan informasi, maka yang dimaksud dengan sistem informasi adalah sejumlah komponen (manusia, komputer, teknologi informasi dan prosedur kerja), ada sesuatu yang diproses (data menjadi informasi), dan dimaksudkan untuk mencapai suatu sasaran atau tujuan [11].

Untuk pengembangan sistem kita mengenal dengan istilah System Development Life Cycle (SDLC) yang merupakan proses pengembangan atau mengubah suatu sistem perangkat lunak dengan menggunakan model-model dan metodelogi yang digunakan orang untuk mengembangkan sistem-sistem perangkat lunak sebelumnya [12]. Perancangan merupakan salah satu tahapan paling penting dalam pengembangan, Menurut Azhar Susanto dalam Akhmad Syukron dan Noor Hasan [13] menjelaskan bahwa perancangan 
adalah spesifikasi umum dan terinci dari pemecahan masalah berbasis komputer yang telah dipilih selama tahap analisis.

\section{Metode Penelitian}

Metode penelitian yang digunakan dalam pengembangan system adalah dengan Model Waterfall sering juga disebut model sekuensial linier (sequential linear) atau daur hidup klasik (classic life cycle). Disebut dengan waterfall karena tahap demi tahap yang dilalui harus menunggu selesainya tahap sebelumnya dan berjalan berurutan seperti terlihat dalam gambar 1 dibawah ini. Pada model Waterfall tahapan yang akan dibahas adalah sebagai berikut :

\subsection{Tahapan Analisis}

Pada Tahapan ini hanya mengambil pada kegiatan pengumpulan data. Metode pengumpulan data dengan menggunakan metode Observasi dilakukan untuk mendapatkan prosedur aktifitas pada sistem pelayanan kesehatan UPTD Puskesmas XYZ dari kegiatan observasi tersebut dapat diketahui kesalahan atau proses dan kegiatan tersebut dan metode wawancara untuk mendapatkan informasi secara lengkap maka penulis melakukan suatu metode tanya jawab dengan karyawan dengan semua kegiatan yang berhubungan dengan pelayanan kesehatan di UPTD Puskesmas XYZ.

\subsection{Tahapan Perancangan (Desain)}

Tahapan perancangan/desain yang terdapat pada gambar 1 merupakan tahapan yang mentranslasikan kebutuhan sistem dari tahap analisis kemudian di representasi ke dalam desain agar dapat diimplementasikan, tools yang dipergunakan dalam perancangan adalah DFD (Data Flow Diagram), ERD (Entity Relationship Diagram) sebagai rancangan model relasi antar database, Rancangan Basis Data, Rancang Input dan Output.

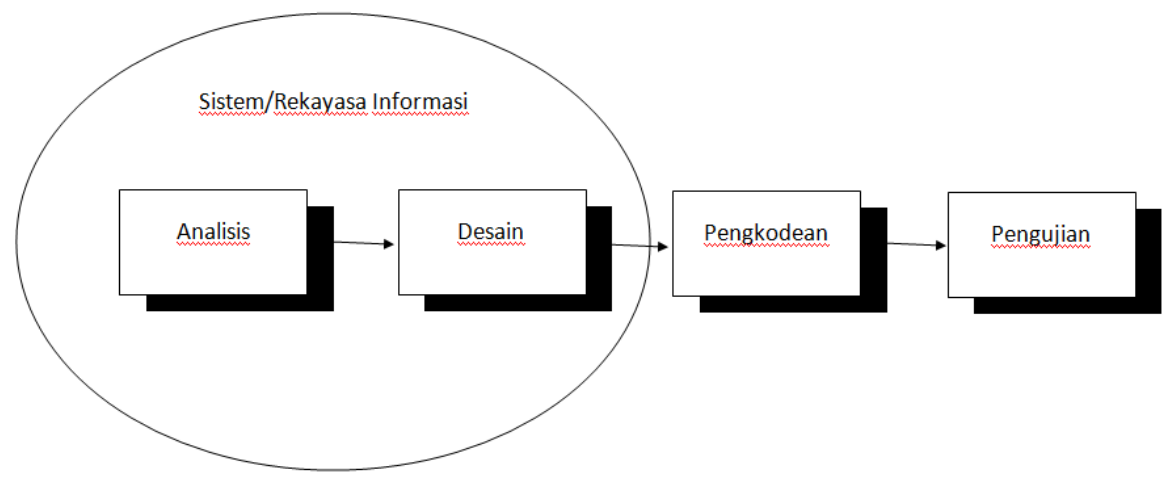

Gambar 1 Model Waterfall

\section{Hasil Dan Pembahasan}

Pada bagian ini akan dijelaskan hasil dan pembahasan berdasarkan tahapan yang terdapat pada metode penelitian. Tahapan pada pembahasan ini hanya mencakup Tahapan Analisis dan Perancangan.

\subsection{Tahapan Analisis}

Tahapan ini dimulai dengan melakukan pengumpulan data, dokumen dan prosedur. 


\subsubsection{Pengumpulan Data}

Hasil dari pengumpulan data dan dokumen dilakukan berdasarkan sumber daya manusia puskesmas terdiri atas tenaga kesehatan dan tenaga non kesehatan[1]. Jenis dan jumlah tenaga kesehatan dan tenaga non kesehatan dihitung berdasarkan analisis beban kerja, dengan mempertimbangkan jumlah pelayanan yang diselenggarakan, jumlah penduduk dan penyebarannya, karakteristik wilayah kerja, ketersediaan fasilitas pelayanan kesehatan dan pembagian waktu kerja. Tenaga medis yang dimiliki oleh UPTD Puskesmas XYZ adalah tiga puluh sembilan (39) orang seperti ditunjukkan pada Tabel 1.

Tabel 1 Tenaga Medis

\begin{tabular}{|l|c|}
\hline \multicolumn{1}{|c|}{ Jabatan } & Jumlah \\
\hline Perawat & 12 orang \\
\hline Dokter Umum & 5 orang \\
\hline Dokter Gigi & 3 orang \\
\hline Tenaga Laboran & 3 orang \\
\hline Tenaga Apotek & 2 orang \\
\hline Bidan Desa & 10 orang \\
\hline Staff & 7 orang \\
\hline \multicolumn{1}{|c|}{ Total } & 39 orang \\
\hline
\end{tabular}

Sumber : UPTD Puskesmas XYZ, 2016

Program pokok puskesmas dilaksanakan sesuai dengan kemampuan tenaga maupun fasilitasnya [14]. UPTD Puskesmas XYZ memiliki sebelas (11) jenis Fasilitas pelayanan yang bisa didapatkan oleh masyarakat seperti terlihat pada Tabel 2. Selain itu juga setiap tahun diadakan program kesehatan untuk meningkatkan pelayanan kesehatan untuk masyarakat dilingkungan UPTD Puskesmas XYZ.

Tabel 2 Jenis Fasilitas Layanan

\begin{tabular}{|c|l|}
\hline No & \multicolumn{1}{|c|}{ Jenis Layanan } \\
\hline 1. & Poli Umum \\
\hline 2. & Poli Gigi \\
\hline 3. & Poli Kesehatan Ibu dan Anak (KIA) \\
\hline 4. & TB/Paru \\
\hline 5. & UGD \\
\hline 6. & PONED \\
\hline 7. & Kesehatan Keliling \\
\hline 8. & Laboratorium \\
\hline 9. & Apotek \\
\hline 10. & Rawat Inap \\
\hline 11. & ISPA/Diare \\
\hline
\end{tabular}

Sumber : UPTD Puskesmas XYZ, 2005

Pada Tabel 3 menggambarkan bahwa UPTD Puskesmas XYZ di setiap bulan ratarata bisa mencapai 1034 pasien pada poli. Rata-rata pasien yang mendaftar sekitar dua puluh (20) hingga tiga puluh (30) pasien pada setiap harinya. 
Tabel 3 Jumlah Kunjungan Pasien pada setiap Poli

\begin{tabular}{|c|l|c|c|}
\hline No & \multicolumn{1}{|c|}{ Poli } & Pasien & $\%$ \\
\hline 1. & Poli Umum & 357 & $34,52 \%$ \\
\hline 2. & Poli Gigi & 199 & $19,24 \%$ \\
\hline 3. & Poli Kes. Ibu \& Anak (KIA) & 440 & $42,55 \%$ \\
\hline 4. & TB/Paru & 38 & $3,67 \%$ \\
\hline Jumlah & $\mathbf{1 , 0 3 4}$ & $\mathbf{1 0 0}$ \\
\hline
\end{tabular}

Sumber : Laporan kunjungan pasien per Desember 2016

\subsubsection{Pengumpulan Dokumen}

Dokumen yang terkait dengan kegiatan pelayanan UPTD Puskesmas XYZ ada 15 dokumen seperti formulir pendaftaran pasien, kartu tanda penduduk, kartu BPJS/JKM/KIS/SKTM, kartu pasien, kartu status pasien (KSP), buku status pasien, surat rujukan, buku surat rujukan, laporan kunjungan, laporan status pasien, laporan data penyakit, laporan rurat rujukan (LSR), laporan data penyakit bulanan, laporan kegiatan pelayanan puskesmas.

\subsubsection{Prosedur-prosedur Sistem Informasi Pelayanan Kesehatan}

Setelah dilakukan pengamatan/observasi terhadap sistem yang sedang berjalan diperoleh beberapa prosedur, yaitu :

\section{Prosedur Pendaftaran Pasien Baru}

1. Calon pasien

a. Formulir pendaftaran yang sudah terisi diberikan kepada bagian pendaftaran beserta kartu identitas dan kartu keluarga

b. Menerima kartu pasien dari bagian pendaftaran

2. Bagian pendaftaran

a. Menerima formulir pendaftaran, kartu identitas dan kartu keluarga dari calon pasien

b. Mengecek data pasien di database

c. Jika data pasien ada, input data formulir pendaftaran dan poli tujuan

d. Jika data pasien tidak tersedia, formulir pendaftaran invalid

e. Mencetak kartu pasien

f. Memberikan kartu pasien, kartu identitas dan kartu keluarga kepada pasien

\section{Prosedur Pendaftaran Pasien Lama}

1. Pasien

a. Memberikan kartu pasien kepada bagian pendaftaran

b. Menerima kartu pasien dari bagian pendaftaran

c. Melampirkan kartu BPJS

2. Bagian Pendaftaran
a. Menerima kartu pasien
b. Mengecek kategori pasien
c. Jika pasien umum, cek data pasien pada database
d. Jika bukan pasien umum, lampirkan kartu BPJS
e. Input poli tujuan pasien
f. Memberikan kartu pasien dan kartu jaminan kesehatan (jika ada) kepada pasien 


\section{Prosedur Pemeriksaan Pasien}

1. Pasien

a. Kartu pasien diberikan kepada bagian pendaftaran.

b. Menerima kartu pasien setelah bagian pendaftaran mencetak kartu status pasien.

c. Menerima surat rujukan dari perawat

2. Bagian Pendaftaran

a. Menerima kartu pasien.

b. Cari kartu status pasien.

c. Jika ada, kartu status pasien diberikan kepada perawat.

d. Jika tidak ada, cetak kartu status pasien.

e. Mengembalikan kartu pasien setelah kartu status pasien dicetak

f. Menerima kartu status pasien yang sudah terisi dari perawat

g. Mengarsipkan kartu status pasien

3. Perawat

a. Menerima kartu status pasien dari bagian pendaftaran.

b. Memberikan katru status pasien kepada dokter

c. Menerima kartu status pasien yang sudah diisi dari dokter

d. Input hasil diagnosa pada database

e. Memberikan kartu status pasien yang sudah terisi kepada bagian pendaftaran

f. Menerima surat rujukan dari dokter

g. Input data surat rujukan dari dokter

h. Memberikan surat rujukan kepada pasien

4. Dokter

a. Menerima kartu status pasien dari perawat

b. Mencatat hasil diagnosa pasien

c. Jika diperlukan tindakan lanjut, buat surat rujukan

d. Jika tidak diperlukan tindakan lanjut, berikan kartu status pasien yang sudah terisi diagnosa kepada perawat

e. Memberikan surat rujukan kepada perawat.

\section{Prosedur Pelaporan}

1. Bagian Pendaftaran

a. Mencetak laporan dari database pasien dan poli

b. Laporan kunjungan pasien diberikan kepada petugas SP3.

2. Perawat

a. Mencetak laporan dari database rekam medis.

b. Laporan status pasien, laporan data penyakit dan laporan surat rujukan diberikan kepada petugas SP3.

3. Petugas SP3

a. Menerima laporan kunjungan pasien dari bagian pendaftaran.

b. Menerima laporan status pasien, laporan data penyakit dan laporan surat rujukan dari perawat

c. Membuat laporan kunjungan pasien menjadi LB4, laporan status pasien dan laporan data penyakit menjadi LB1

d. Memberikan hasil klasifikasi laporan kepada kepala puskesmas

4. Kepala Puskesmas

a. Menerima hasil laporan dari petugas SP3

b. Mengarsipkan laporan surat rujukan 
c. Memberikan cap dan tanda tangan pada laporan

d. Setiap periode laporan LB1 dan LB4 diberikan kepada Dinas Kesehatan

\subsection{Tahapan Perancangan}

Pada tahapan ini alat yang digunakan adalah mulai dari DFD (Data Flow Diagram), ERD (Entity Relationship Diagram) sebagai rancangan model relasi antar database, sampai Rancang Input dan Output.

\subsubsection{Data Flow Diagram (DFD)}

Penggambaran sistem baik itu secara manual maupun terkomputerisasi dengan menggunakan diagram disusun berdasarkan komponen-komponen sistem yang saling berinteraksi sesuai dengan aturan [9].

\section{Diagram Konteks}

Penggambaran sistem informasi secara umum digambarakan dengan menggunakan Diagram Konteks (DK). Pada DK seperti pada gambar 2 memiliki 4 entitas luar yang berinteraksi dengan Sistem Informasi Pelayanan Kesehatan (SIYANKES). Entitas Luar tersebut yaitu : Calon Pasien, Pasien, Dokter, Kepala Puskesmas (Ka.Puskesmas).

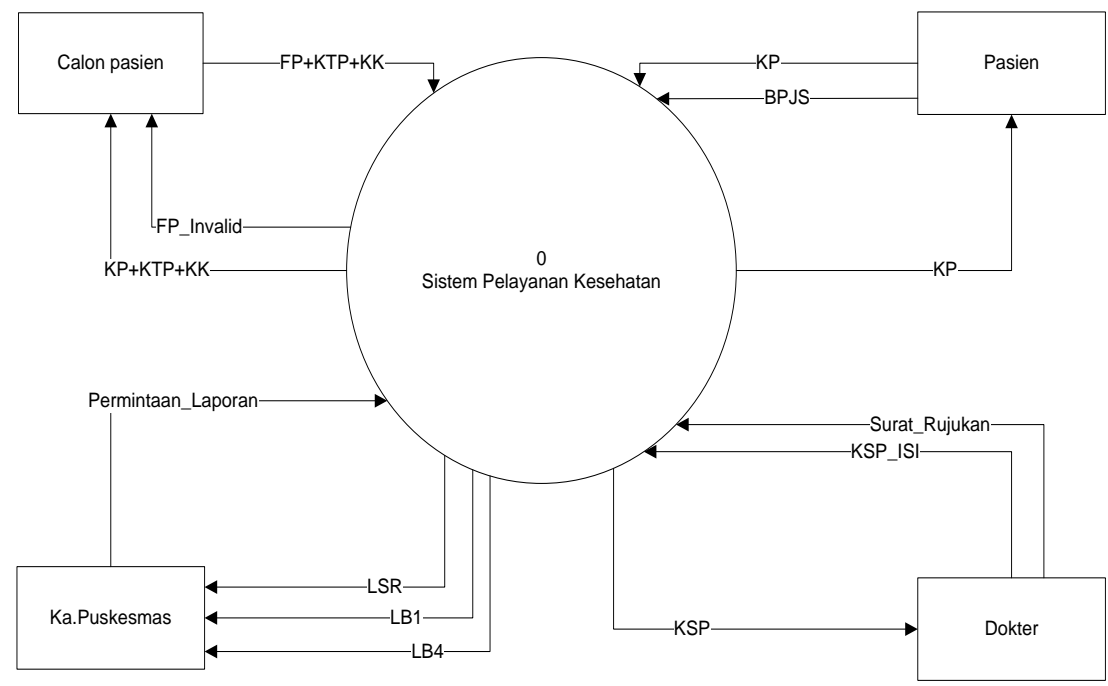

Gambar 2 Diagram Konteks

2. Data Flow Diagram (DFD) Level 1

DFD level 1 pada SIYANKES memiliki tiga proses utama seperti yang terlihat pada gambar 3, yaitu Pendaftaran, Pemeriksaan, dan Pelaporan. Proses Pendaftaran (P1) memproses data pasien dan calon pasien yang akan berobat, kemudian meng-update data store Poli dan Pasien. Proses Pemeriksaan (P2) mendapatkan data masukan dari Pasien dan Dokter yang hasil prosesnya disimpan dalam data store Pasien, Karyawan, dan Rekam Medis (RM). Proses yang ketiga Pelaporan (P3) membuat laporan LSR, LB1, dan LB4 yang memproses data dari datastore Poli, Pasien, dan RM. 


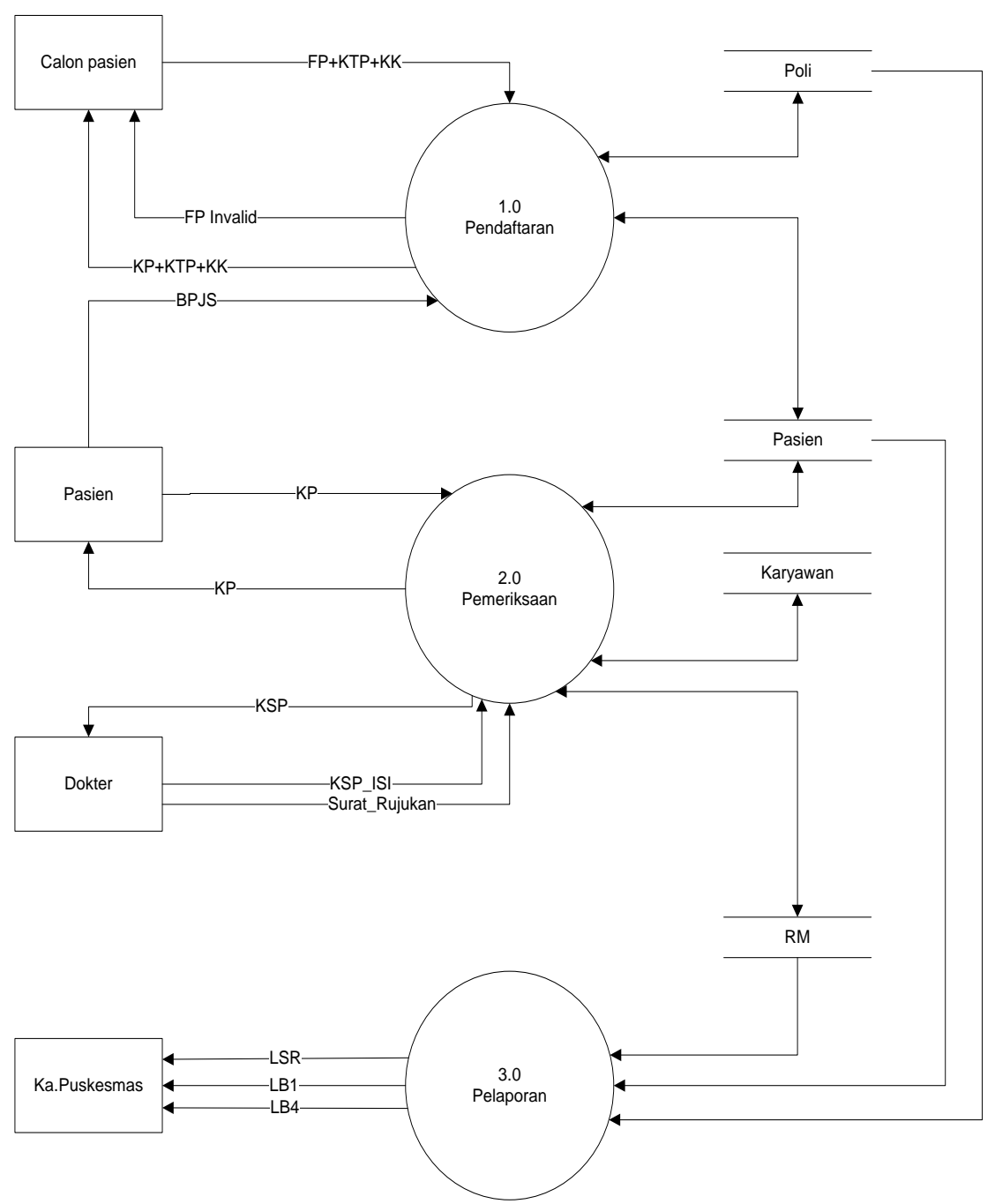

Gambar 3 Data Flow Diagram Level 0

\subsubsection{Entity Relationship Diagram (ERD)}

ERD merupakan penggambaran hubungan antar data ddari suatu database. ERD SIYANKES adalah seperti yang terlihat pada gambar 8 dengan penjelasan sebagai berikut : Relasi entitas pasien dengan entitas poli memiliki hubungan antar entitas Many to Many dimana beberapa pasien dapat mendaftar dibeberapa poli begitu juga sebaliknya.

Relasi entitas poli dengan entitas karyawan memiliki hubungan antar entitas One to Many. Dimana satu poli bisa dikelola oleh beberapa karyawan, begitu juga sebaliknya beberapa karyawan hanya bisa mengelola hanya satu poli saja.

Relasi entitas pasien dengan entitas rekam medis memiliki hubungan antar entitas One to Many. Dimana satu pasien bisa memiliki lebih dari satu atau beberapa rekam medis. Dikarenakan setiap lima tahun terjadi pergantian rekam medis. Relasi entitas rekam medis dengan entitas rekam medis detail memiliki hubungan antar entitas One to Many. Dimana satu rekam medis dapat memiliki beberapa detail atau rincian hasil dari diagnosa.

Pada gambar 4, entitas pasien dengan entitas surat rujukan memiliki hubungan antar entitas One to Many. Dimana satu pasien bisa tidak mendapatkan atau mendapatkan satu atau lebih surat rujukan. 


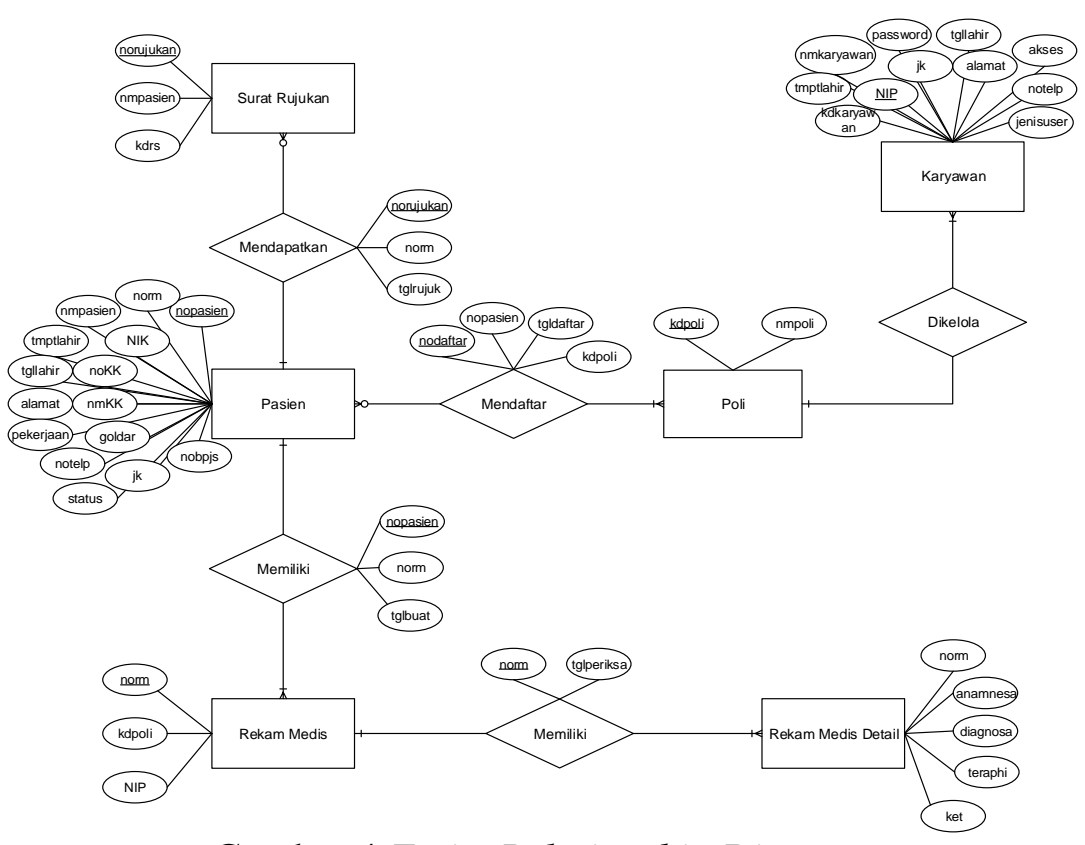

Gambar 4 Entity Relationship Diagram

\subsubsection{Perancangan Antarmuka/Interface}

Adapun perancangan antarmuka terdiri atas dua (2) yaitu perancangan masukan dan perancangan keluaran.

\section{Perancangan Masukan/Input}

Perancangan masukan yang dirancang berdasarkan dokumen dan rancangan database yang sudah dirancang pada pembahasan diatas.

\section{a. Data Karyawan}

Rancangan masukan pada gambar 5 berfungsi untuk memasukan seluruh data karyawan yang ada pada puskesmas tersebut. Proses pemasukan data dimulai dari memasukan Nomor Induk Pegawai (NIP) kemudian memasukan Nama Karyawan dan seterusnya sesuai dengan urutan yang terdapat pada Tabel 4 .

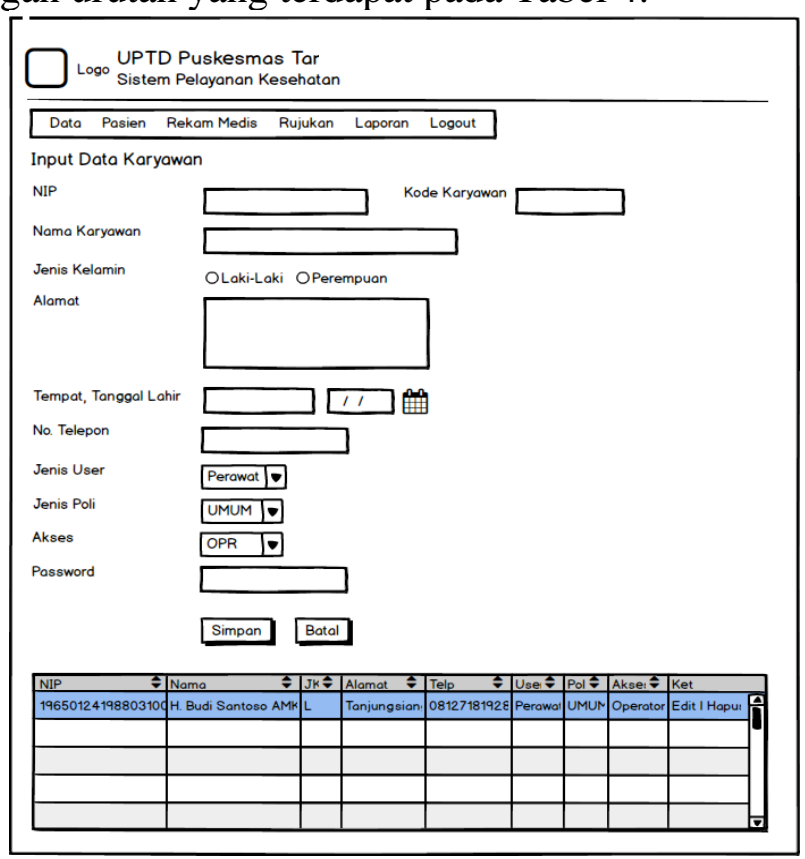

Gambar 5 Rancangan Masukan Data Karyawan 
Tabel 4 Penjelasan Gambar Rancangan Masukan Data Karyawan

\begin{tabular}{|c|l|c|c|l|}
\hline No. & \multicolumn{1}{|c|}{ Label } & Komponen & Panjang & \multicolumn{1}{c|}{ Keterangan } \\
\hline 1 & NIP & Textfield & 18 & Input Nomor Induk Pegawai \\
\hline 2 & Nama Karyawan & Textfield & 6 & Input Nama Karyawan \\
\hline 3 & Jenis Kelamin & Option & 1 & Laki-laki dan Perempuan \\
\hline 4 & Alamat & Textfield & 50 & Input Alamat Lengkap \\
\hline 5 & Tempat Lahir & Textfield & 15 & Input Tempat Lahir (Kabupaten) \\
\hline 6 & Tanggal Lahir & Textfield & 10 & Input Tgl Lahir (kalender) \\
\hline 7 & No. Telp & Textfield & 12 & Input No Telepon/Handphone \\
\hline 8 & Jenis User & Combo & 15 & Input Posisi/jabatan user \\
\hline 9 & Jenis Poli & Combo & 15 & Input Poli Penempatan Karyawan \\
\hline 10 & Akses & Combo & 12 & Input hak akses sistem \\
\hline 11 & Password & Textfield & 15 & Input Password bagi user kary. \\
\hline
\end{tabular}

\section{b. Pendaftaran Pasien}

Rancangan masukan pendaftaran pasien ini diperuntukkan pendaftaran pasien saat akan melakukan pemeriksaan pada UPTD Puskesmas bisa dilihat pada gambar 6 dibawah ini. Proses pemasukan data dimulai dengan memasukan No. Pendaftaran terlebih dahulu secara otomatis oleh system sehingga tidak akan terjadi no. pendaftaran ganda selanjutnya memasikan No. Pasien sesuai dengan No yang tertera pada Kartu Pasien yang harus dibawa setiap akan berobat. Selanjutnya urutan pemasukan data sesuai yang tertera pada Tabel 5.

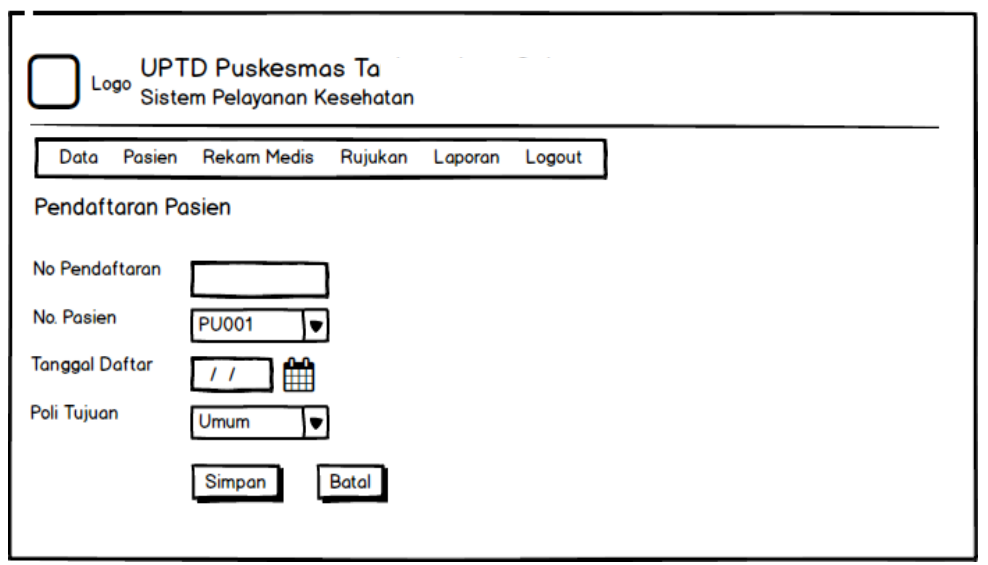

Gambar 6 Rancangan Masukan Data Pendaftarn Pasien

Tabel 5 Penjelasan Gambar Rancangan Masukan Data Pendaftaran Pasien

\begin{tabular}{|c|l|c|c|l|}
\hline No. & \multicolumn{1}{|c|}{ Label } & Komponen & Panjang & \multicolumn{1}{c|}{ Keterangan } \\
\hline 1 & No. Pendaftaran & Textfield & 5 & Input Nomor Pendaftaran \\
\hline 2 & No. Pasien & Textfield & 5 & Input Nomor Pasien \\
\hline 3 & Tanggal Daftar & Textfield & 10 & Input Tgl Pendaftaran (kalender) \\
\hline 4 & No. Telp & Textfield & 12 & Input No Telepon/Handphone \\
\hline 5 & Poli Tujuan & Combo & 15 & Input Poli Tujuan Pasien \\
\hline
\end{tabular}

\section{c. Biodata Pasien}

Biodata pasien merupakan data penting yang dibutuhkan oleh UPTD Puskesmas, oleh karena itu dalam memasukan biodata pasien ini diperlukan suatu interface untuk memudahkan memasukan data. Rancangan interface adalah seperti pada gambar 7. 
Memasukan biodata pasien dimulai dengan memasukan No. Pasien, setelah itu memasukan No. RM (Rekam Medis), memasukan No. Kartu Keluarga seterusnya sesuai dengan urutan yang tertera pada Tabel 6.

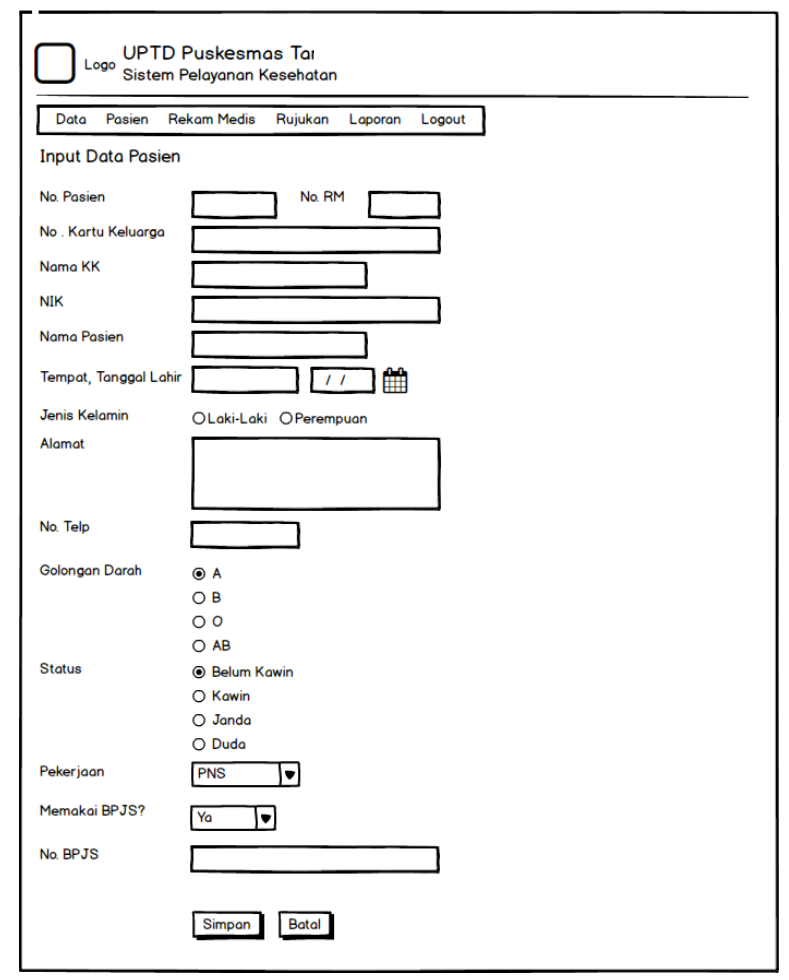

Gambar 7 Rancangan Masukan Biodata Pasien

Tabel 6 Penjelasan Gambar Rancangan Masukan Biodata Pasien

\begin{tabular}{|c|l|c|c|l|}
\hline No. & \multicolumn{1}{|c|}{ Label } & Komponen & Panjang & \multicolumn{1}{c|}{ Keterangan } \\
\hline 1 & No. Pasien & Textfield & 5 & Input Nomor Pasien \\
\hline 2 & No. Rekam Medis & Textfield & 6 & Input No. Rekam Medis \\
\hline 3 & No. KK & Textfield & 16 & Input No Kartu Keluarga \\
\hline 4 & Nama KK & Textfield & 50 & Input Nama Kepala Keluarga \\
\hline 5 & NIK & Textfield & 16 & Input Nomor Induk Kependudukan \\
\hline 6 & Nama Pasien & Textfield & 50 & Input Nama Pasien \\
\hline 7 & Tempat Lahir & Textfield & 15 & Input Tempat Lahir (Kabupaten) \\
\hline 8 & Tanggal Lahir & Textfield & 10 & Input Tgl Lahir (kalender) \\
\hline 9 & Jenis Kelamin & Option & 1 & Pilih Laki-laki atau Perempuan \\
\hline 10 & Alamat & Textfield & 50 & Input Alamat Lengkap \\
\hline 11 & No. Telp & Textfield & 12 & Input No Telepon/Handphone \\
\hline 12 & Golongan Darah & Option & 1 & Pilih A, B, AB atau O \\
\hline 13 & Status & Option & 1 & Pilih Status Pernikahan (Blm Kawin, \\
& & Kawin, Janda, atau Duda) \\
\hline 10 & Pekerjaan & Combo & 12 & Pilih Jenis Pekerjaan \\
\hline 11 & No. BPJS & Textfield & 13 & Input No Kepesertaan BPJS \\
\hline
\end{tabular}

\section{d. Rekam Medis}

Seorang pasien harus memiliki catatan riwayat tindakan dan pelayanan yang berisikan antara lain biodata pasien, hasil pemeriksaan, catatan pemberian obat[15]. 
Perancangan untuk memasukan data Rekam Medis (RM) (gambar 8) Sembilan (9) fields yang dimulai dengan memasukan No. pasien, kemuadian No. RM. Setelah itu anda bisa memasukan nama poli dimana pasien itu diperiksa kemudian mamasukan NIP dokter yang memeriksa, seterusnya fields seluruhnya berdasarkan urutan yang tercantum pada Tabel 7.

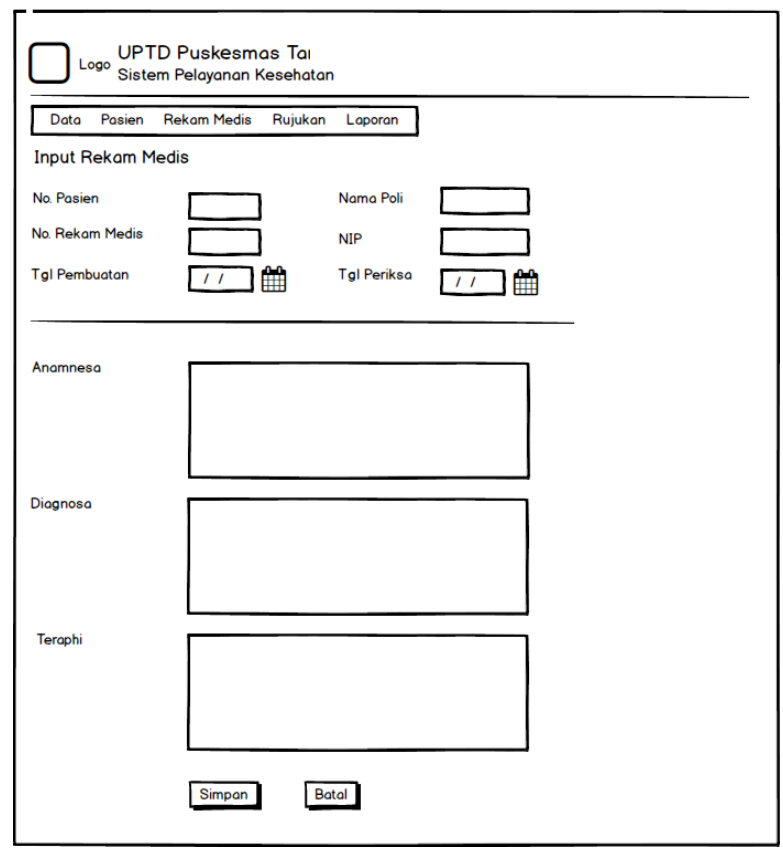

Gambar 8 Rancangan Masukan Rekam Medis

Tabel 7 Penjelasan Gambar Rancangan Masukan Rekam Medis

\begin{tabular}{|c|l|c|c|l|}
\hline No. & \multicolumn{1}{|c|}{ Label } & Komponen & Panjang & \multicolumn{1}{c|}{ Keterangan } \\
\hline 1 & No. Pasien & Textfield & 5 & Input Nomor Pasien \\
\hline 2 & No. Rekam Medis & Textfield & 6 & Input No. Rekam Medis \\
\hline 3 & Tanggal Buat RM & Textfield & 10 & Input Tgl Buat RM (kalender) \\
\hline 4 & Nama Poli & Combo & 15 & Input Poli Tujuan Pasien \\
\hline 5 & NIP & Textfield & 18 & Input NIP khusus Dokter \\
\hline 6 & Anamnesa & Textfield & 200 & Input Gejala dirasakan Pasien \\
\hline 7 & Diagnosa & Textfield & 200 & Input Hasil Pemeriksaan Dokter \\
\hline 8 & Teraphi & Textfield & 200 & Input Pengobatan Pasien \\
\hline 9 & Keterangan & Textfield & 200 & Input Catatan Tamb. hasil periksa \\
\hline
\end{tabular}

\section{e. Surat Rujukan}

Rancangan masukan seperti pada gambar 9 memberikan kemudahan kepada dokter dalam membuat surat rujukan. Untuk membuat Surat Rujukan seorang dokter harus memasukan No. Surat Rujukan terlebih dahulu, setelah itu No. RM seterusnya mengikuti sesuai dengan urutan yang terdapat pada Tabel 8. 


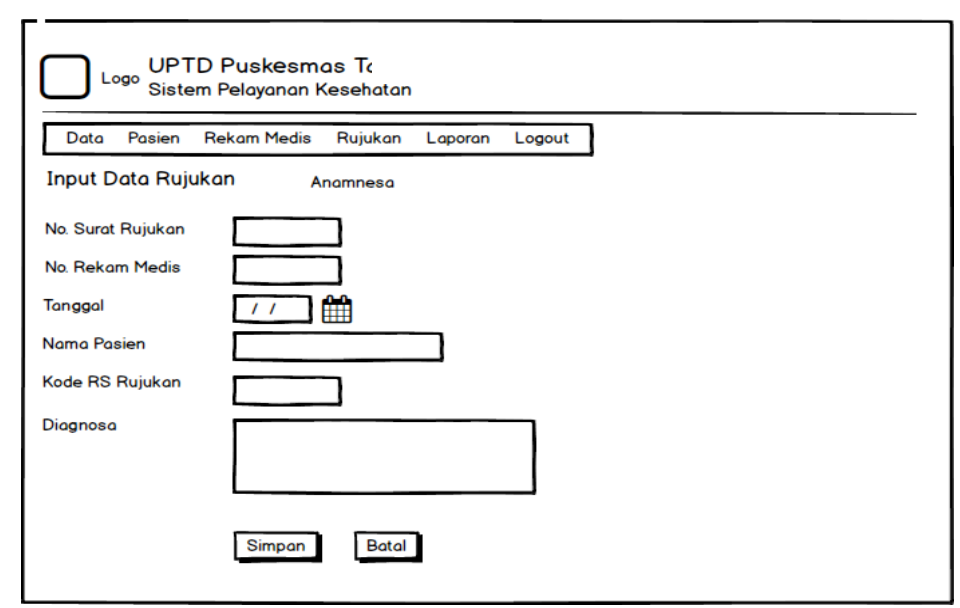

Gambar 9 Rancangan Masukan Surat Rujukan

Tabel 8 Penjelasan Gambar Rancangan Masukan Surat Rujukan

\begin{tabular}{|c|l|c|c|l|}
\hline No. & \multicolumn{1}{|c|}{ Label } & Komponen & Panjang & \multicolumn{1}{c|}{ Keterangan } \\
\hline 1 & No. Surat Rujukan & Textfield & 10 & Input Nomor Surat Rujukan ke RS \\
\hline 2 & No. Rekam Medis & Textfield & 6 & Input No. Rekam Medis \\
\hline 3 & Tanggal & Textfield & 10 & Input Tgl Buat Rujukan (kalender) \\
\hline 4 & Nama Pasien & Textfield & 50 & Input Nama Pasien \\
\hline 5 & Kode RS Rujukan & Textfield & 5 & Input Kode Rumah Sakit \\
\hline 6 & Diagnosa & Textfield & 200 & Input Hasil Pemeriksaan Dokter \\
\hline
\end{tabular}

\section{Perancangan Keluaran/Output}

Perancangan keluaran merupakan gambaran tentang keluaran yang disajikan oleh sistem, baik berupa keluaran dilayar/display maupun keluaran yang berbentuk cetakan.

Dari seluruh rancangan keluaran yang ada rancangan keluaran yang berbentuk laporan adalah sebagai berikut :

\section{a. Laporan Kunjungan Pasien}

Interface pada gambar 10 merupakan laporan kunjungan pasien kunjungan pendaftaran maupun pemeriksaan pasien periode tertentu/rentang tanggal tertentu.

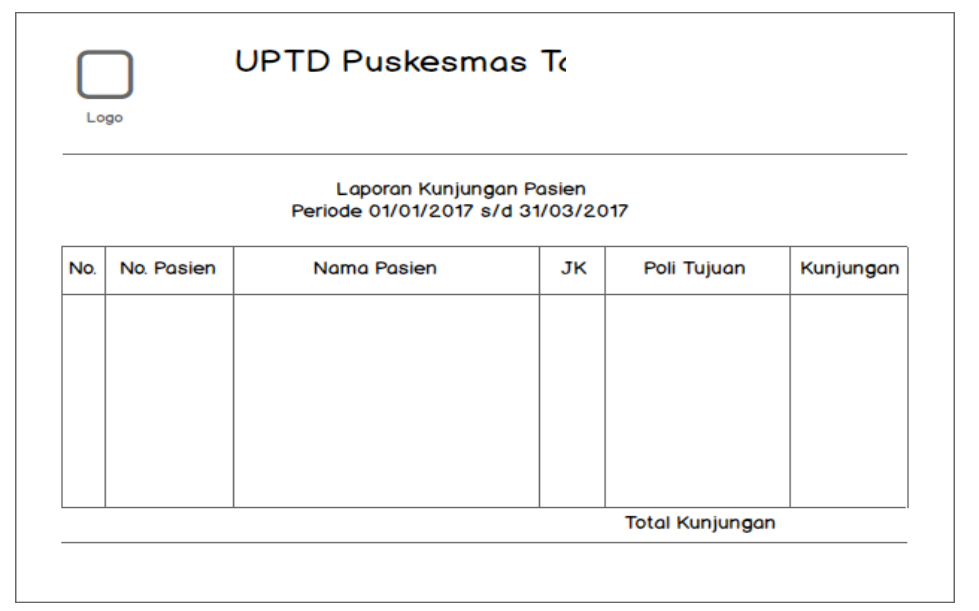

Gambar 10 Rancangan Keluar Laporan Kunjungan Pasien 


\section{b. Laporan Data Penyakit}

Rancangan Laporan Data Penyakit ini menggambarkan keadaan jumlah pasien berdasarkan jenis kelamin dengan jenis penyakit apa yang ditangani oleh setiap poli pada periode tertentu. Rancangannya seperti pada gambar 11.

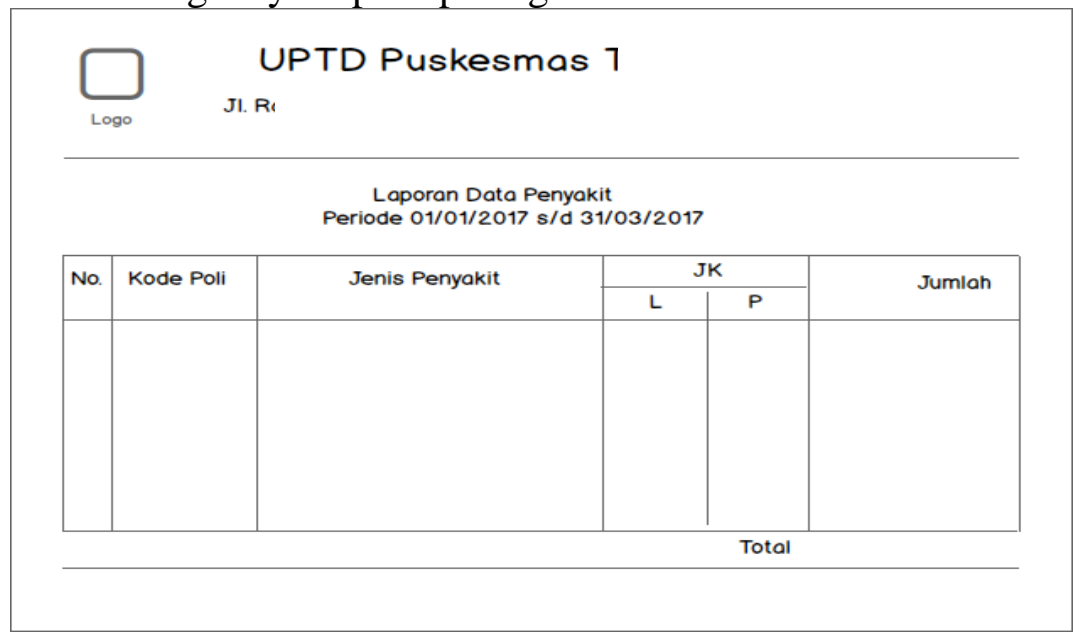

Gambar 11 Rancangan Keluaran Laporan Data Penyakit

\section{c. Laporan Surat Rujukan}

Rancangan keluaran Laporan Surat Rujukan seperti pada gambar 12 untuk mengetahui surat rujukan yang dikeluarkan oleh UPTD puskesmas dalam periode tertentu.

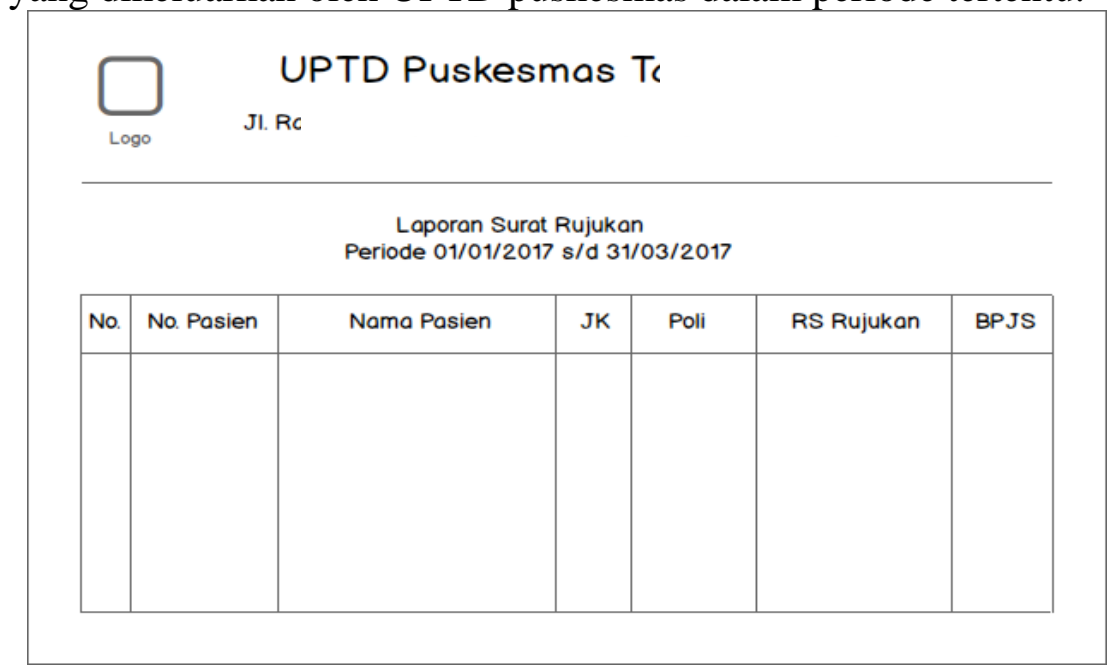

Gambar 12 Rancangan Keluaran Laporan Surat Rujukan

\section{Kesimpulan}

Sistem informasi pelayanan kesehatan yang sudah dirancang diharapkan akan sangat membantu dalam mempercepat pengelolaan pendaftaran pasien dan data Pasien, serta mempermudah pengarsipan secara digital hasil pemeriksaan dokter agar meminimalisir terjadinya kehilangan/rusak dokumen rekam medis, sehingga pelaporan kepada petugas SP3 menjadi lebih mudah. Kendala yang sering terjadi adalah pada saat hasil rancangan ini akan diimplementasikan yaitu sumber daya manusia yang akan mengoperasikan sistem pelayanan kesehatan ini dari segi jumlah maupun kemampuan. Oleh sebab itu untuk kelancaran pada tahap implementasi saya sarankan harus dilakukan pelatihan pengoperasikan sistem ini untuk semua operator/pengguna. 


\section{Daftar Pustaka}

[1] R. Kemenkes, "Permenkes RI Nomor 75 Tahun 2014 Tentang Puskesmas," Kementrian Kesehat., 2014, doi: 10.1038/132817a0.

[2] M. F. Efendi, Keperawatan Kesehatan Komunitas Teori dan Praktik dalam Keperawatan. Jakarta: Salemba Medika, 2009.

[3] Kementrian Kesehatan RI, Permenkes RI Nomor 1 tahun 2012 tentang Sistem Rujukan Pelayanan Kesehatan Perorangan. 2012.

[4] Z. Arifin and A. Kurniadi, "Sistem Informasi Pendaftaran Pasien Rawat Jalan di Puskesmas Juwana Kabupaten Pati Tahun 2012," VisiKes UDINUS Semarang, vol. 12, no. 2, pp. 147-155, 2013.

[5] D. Budiarti, J. W. Fernanda, and M. C. Untoro, "Sistem Informasi Indeks Untuk Rekam Medis," J. MIKI Inst. Ilmu Kesehat. Bhakti Wiyata Kediri, vol. 3, no. 2, pp. 58-67, 2015.

[6] F. Rohman, A. B. Setiawan, and I. Fauzi, "Perancangan Sistem Pelayanan Kesehatan Prima Puskesmas Terpadu Pada Dinas Kesehatan Kabupaten Kediri," in Seminar Nasional Teknologi Informasi dan Multimedia, 2014, pp. 2.10-2.19, ISSN : 2302-3805.

[7] Y. Purwasandina, E. Gunadhi, and D. Destiani Siti Fatimah, "Rancang Bangun Sistem Informasi Pengelolaan Data Rujukan Pasien Untuk Puskesmas Pembangunan Garut," J. Algoritm., vol. 12, no. 2, pp. 393-397, 2015, doi: 10.33364/algoritma/v.12-2.393.

[8] B. Nugroho, S. H. Fitriasih, and B. Widada, "Sistem Informasi Rekam Medis di Puskesmas Masaran I Sragen," J. TIKomSiN, vol. 3, no. 2, pp. 49-56, ISSN : 23384018, 2015, doi: 10.30646/TIKOMSIN.V3I2.203.

[9] T. Sutabri, Analisis Sistem Informasi. Yogyakarta, 2012.

[10] Jeperson Hutahean, "Konsep Sistem Informasi - Jeperson Hutahaean - Google Buku," Deepublish. Deepublish, Yogyakarta, 2015.

[11] Abdul Kadir, Pengenalan Sistem Informasi Edisi Revisi, Revisi. Yogyakarta: Andi Publisher, 2014.

[12] Rosa dan Shalahuddin, Rekayasa Perangkat Lunak (Terstrukur dan Berorientasi Objek). Bandung: Informatika Bandung, 2016.

[13] A. Syukron and N. Hasan, "Perancangan Sistem Informasi Rawat Jalan Berbasis Web Pada Puskesmas Winong," J. Bianglala Inform., vol. 3, no. 1, pp. 28-34, ISSN : 2338-9761, 2015, doi: 10.31294/bi.v3i1.574.

[14] R. I. Kementerian Hukum dan HAM, Peraturan Menteri Kesehatan Nomor 44 Tahun 2016 tentang Pedoman Manajemen Puskesmas. 2016.

[15] Permenkes, "Permenkes No. 269/Menkes/Per/III/2008," Peraturan Menteri Kesehatan Republik Indonesia Nomor 269. 2008. 